\title{
Methionine sulphoxide reductases protect iron- sulphur clusters from oxidative inactivation in yeast
}

\author{
Correspondence \\ Simon V. Avery \\ Simon.Avery@nottingham.ac.uk
}

Received 25 July 2008

Revised 15 October 2008

Accepted 22 October 2008

\author{
Theodora C. Sideri,† Sylvia A. Willetts and Simon V. Avery \\ School of Biology, Institute of Genetics, University of Nottingham, Nottingham NG7 2RD, UK
}

\begin{abstract}
Methionine residues and iron-sulphur ( $\mathrm{FeS}$ ) clusters are primary targets of reactive oxygen species in the proteins of micro-organisms. Here, we show that methionine redox modifications help to preserve essential FeS cluster activities in yeast. Mutants defective for the highly conserved methionine sulphoxide reductases (MSRs; which re-reduce oxidized methionines) are sensitive to many pro-oxidants, but here exhibited an unexpected copper resistance. This phenotype was mimicked by methionine sulphoxide supplementation. Microarray analyses highlighted several $\mathrm{Cu}$ and $\mathrm{Fe}$ homeostasis genes that were upregulated in the $m x r \Delta$ double mutant, which lacks both of the yeast MSRs. Of the upregulated genes, the Cu-binding Fe transporter Fet3p proved to be required for the Cu-resistance phenotype. FET3 is known to be regulated by the Aft1 transcription factor, which responds to low mitochondrial FeS-cluster status. Here, constitutive Aft $1 p$ expression in the wild-type reproduced the Cu-resistance phenotype, and $\mathrm{FeS}$-cluster functions were found to be defective in the $m x r \Delta$ mutant. Genetic perturbation of FeS activity also mimicked FET3-dependent $\mathrm{Cu}$ resistance. ${ }^{55} \mathrm{Fe}$-labelling studies showed that $\mathrm{FeS}$ clusters are turned over more rapidly in the $m x r \Delta$ mutant than the wild-type, consistent with elevated oxidative targeting of the clusters in MSR-deficient cells. The potential underlying molecular mechanisms of this targeting are discussed. Moreover, the results indicate an important new role for cellular MSR enzymes in helping to protect the essential function of FeS clusters in aerobic settings.
\end{abstract}

\section{INTRODUCTION}

Reactive oxygen species (ROS) are generated continuously through the process of respiration in all aerobic organisms, and may cause the oxidative deterioration of lipid, DNA and protein function in cells (Temple et al., 2005). ROS damage is often exacerbated during stress. To counter this, cells have evolved a range of enzymic and non-enzymic antioxidant defence mechanisms. The majority of these serve a preventative role in scavenging ROS before they exert damage. Others repair incurred oxidative damage,

tPresent address: Faculty of Life Sciences, Michael Smith Building, University of Manchester, Oxford Road, Manchester M13 9PT, UK.

Abbreviations: AAS, atomic absorption spectrophotometry; BCS, bathocuproine disulphonic acid; FeS cluster, iron-sulphur cluster; MetO, methionine sulphoxide; MSR, methionine sulphoxide reductase; qRTPCR, quantitative real-time PCR; ROS, reactive oxygen species.

Five supplementary figures, showing $\mathrm{Cu}$ resistance in the fet $4 \Delta, m \times r \Delta$ and $m \times r \Delta /$ fet $4 \Delta$ mutants, that overexpression of FET3 or SOD1 confers Cu resistance, that CUP1 may partially contribute to the Cu resistance of the $m \times r \Delta$ mutant, Bio2 protein in immunoprecipitates from wild-type and $m x r \Delta$ cells, and determination of ${ }^{55} \mathrm{Fe}$ incorporation into $\mathrm{FeS}$ proteins, and a supplementary table listing genes upregulated at least twofold in $m s r$ versus wild-type cells, are available with the online version of this paper. including phospholipid hydroperoxide glutathione peroxidases (lipid peroxidation) (Avery et al., 2004) and 8-oxoG DNA glycosylases (DNA oxidation) (Boiteux \& Radicella, 1999). The principal enzymic mechanism for reversing protein oxidation acts on the oxidation product of just one amino acid residue, methionine. This specificity for Met reflects the fact that Met is particularly susceptible to oxidation compared with other amino acids. Furthermore, Met oxidation has been linked to Alzheimer's (Schoneich, 2005) and Parkinson's (Wassef et al., 2007) diseases. Methionine sulphoxide reductases (MSRs) are conserved across nearly all organisms from bacteria to humans (Kryukov et al., 2002), and have been the focus of considerable attention in recent years. Two MSR activities have been characterized in the yeast Saccharomyces cerevisiae: MsrA (encoded by MXR1) reduces the S stereoisomer of methionine sulphoxide (MetO), while MsrB (encoded by the YCL033c ORF, which we term here MXR2) reduces the $\mathrm{R}$ stereoisomer of MetO (Koc et al., 2004; Kryukov et al., 2002). Consistent with defence against oxidative damage, mutants deficient in MSR activity are hypersensitive to pro-oxidants such as $\mathrm{H}_{2} \mathrm{O}_{2}$, paraquat and $\mathrm{Cr}$, while MSR overexpression enhances resistance (Kryukov et al., 2002; Moskovitz et al., 1997, 1998; Sumner et al., 2005). In addition to countering protein 
damage caused by MetO, it has been proposed that MSR activity acts to support an ROS-scavenging function of reduced and surface-exposed Met residues (Levine et al., 1996; Melkani et al., 2006). Furthermore, reversible oxidation of Met residues may serve as a mechanism for regulating protein activity and in cellular signalling processes (for reviews see Bigelow \& Squier, 2005; Moskovitz, 2005).

Besides methionine residues, iron-sulphur (FeS) clusters are exquisitely ROS-sensitive components of many $(>120)$ cellular proteins. FeS clusters are highly abundant and diversely employed enzymic cofactors that have ancient origins (Imlay, 2006). FeS cluster biogenesis is the only known process for which mitochondria are essential to yeast cells (Lill \& Kispal, 2000). FeS clusters participate in electron transfer (featuring commonly in redox enzymes), substrate binding and activation, iron-sulphur storage and regulation of gene expression (Johnson et al., 2005). Haemoglobin formation in differentiating red blood cells is regulated through FeS cluster assembly (Wingert et al., 2005), and decreased activity of FeS enzymes is a characteristic feature of the neurodegenerative disease Friedreich's ataxia (Shan et al., 2007). The vulnerability of FeS clusters to oxygen and oxidative stress greatly complicates their roles in biology. Oxidation of FeS causes loss of protein function, and at the same time releases free Fe which may participate in Fenton catalysis to exacerbate oxidative stress (Keyer \& Imlay, 1996; Srinivasan et al., 2000). Denaturation of FeS clusters is not the only way in which these co-factors may influence cellular Fe availability. A signal which represses the Fe regulon (and so the uptake of $\mathrm{Fe}$ ) at high cellular $\mathrm{Fe}$ levels in yeast is transmitted through a product of the mitochondrial FeS biogenesis machinery (Chen et al., 2004; Kumanovics et al., 2008; Rutherford et al., 2005). Thus, Fe levels influence FeS biogenesis, which in turn regulates Fe homeostasis. Iron homeostasis in yeast also interplays closely with homeostasis of another essential but potentially toxic Fenton catalyst, copper (Askwith \& Kaplan, 1998). The highaffinity Fe transporter Fet3p requires bound copper for activity, and this $\mathrm{Cu}$ binding contributes to cellular $\mathrm{Cu}$ resistance (Stoj et al., 2007). However, direct links between cellular FeS cluster status and $\mathrm{Cu}$ transport or toxicity have not been established to date. The same is true of FeS clusters and Met residues, despite their shared notoriety as highly oxidation-sensitive components of cellular proteins.

In this report, an unexpected Cu-resistance phenotype of MSR-deficient S. cerevisiae cells was traced to activation of the $\mathrm{Fe}$ regulon, specifically FET3. Moreover, it was established that MSR activity helps to preserve the function of cellular FeS clusters. The finding suggests that the ubiquity of MSR enzymes could be an adaptation that enables the operation of FeS clusters in aerobic settings.

\section{METHODS}

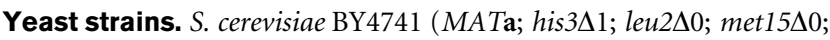
ura $3 \Delta 0$ ) and the isogenic deletion strains aft $1 \Delta$, aft $2 \Delta, \operatorname{ctr} 1 \Delta, \operatorname{cup} 5 \Delta$, fet $3 \Delta$, fet $4 \Delta, m x r 1 \Delta, m x r 2 \Delta(Y C L 033 c \Delta)$, sod $1 \Delta$, and sod $2 \Delta$, in which the specified ORFs are replaced with the KanMX4 marker, were obtained from Euroscarf. Short flanking homology (SFH)-PCR (Longtine et al., 1998) was used to disrupt additional genes (see below) in this study; all primer sequences are available on request. SFH-PCR products were transformed into S. cerevisiae by the lithium acetate method (Gietz \& Woods, 2002), and transformants were selected on yeast nitrogen base (YNB) without amino acids (Formedium), supplemented as required to give appropriate selection (Ausubel et al., 2007). To select for the hphNT1 marker (see below), transformants were plated on YEPD medium (see below) supplemented with $150 \mu \mathrm{g}$ hygromycin $\mathrm{ml}^{-1}$ (Invitrogen). Diagnostic PCR (Longtine et al., 1998) was used to confirm appropriate gene disruption in transformants. Where used, colony PCR for diagnosis of gene disruption was according to Amberg et al. (2005). An mxr $\Delta$ double mutant (mxr1::KAN, mxr2::hphNT1) isogenic with BY4741 was constructed using pFA6a-hphNT1 (Janke et al., 2004) as the template for SFH-PCR-based disruption of MXR2 in the S. cerevisiae $m x r 1 \Delta$ background. A previously constructed $m x r$ double-mutant strain (mxr1::URA3, mxr2::KanMX4, isogenic with BY4741) (Kryukov et al., 2002) was used for further gene deletions in the $m x r \Delta$ background. SFH-PCR was used to disrupt the following genes in the $m x r \Delta$ background and, where specified in the Results, also in the BY4741 wild-type strain: CTR1, FET3, FET4, SOD1, CUP5, CUP11, AFT2 (all with the His3MX6 marker), AFT1 (with the hphNT1 marker). It was confirmed that the markers themselves did not influence $\mathrm{Cu}$ resistance. The LEU2 marker, amplified from pRS315 as template, was used for disruption of CUP1-2 in the cup1-1 $1 \Delta$ and $m \times r \Delta /$ cup1-1 $1 \Delta$ backgrounds. FET3 was disrupted in the cup $1 \Delta, m x r \Delta /$ cup1 $\Delta$ and sod2 $\Delta$ strains with $h p h N T 1$. A disruption construct described elsewhere (Portnoy et al., 2001) was used to delete CTR2, following linearization of plasmid pJS411 with BamHI and transformation into S. cerevisiae BY4741 or $m x r \Delta$ cells.

Plasmids. Standard cloning procedures (Ausubel et al., 2007), reagents from New England Biolabs and the cloning host Escherichia coli $\mathrm{DH} 5 \alpha$ were used throughout. For complementation, a fragment comprising the MXR1 ORF and native promoter was cloned between the NotI and BamHI sites of the single-copy vector pRS315-hphNT1. pRS315-hphNT1 was constructed previously by ligating the hphNT1 marker excised from pFA6a-hphNT1 between the BbsI and NarI sites of pRS315. For overexpression of SOD1 or FET3, fragments encompassing these ORFs plus their native promoters were amplified from yeast genomic DNA and ligated between the KpnI and SalI (SOD1) or EcoRI and XbaI (FET3) sites of the multicopy vector YEp352. Yeast transformants were selected on YNB-minus-uracil medium. An AFT1- ${ }^{\text {up }}$ fragment was released from pRS313-AFT1-1 ${ }^{\text {up }}$ (Chen \& Kaplan, 2000) by digestion with SacI and SpeI. This $3.6 \mathrm{~kb}$ fragment was ligated into pRS315-hphNT1. Yeast transformants were selected in YEPD agar supplemented with $150 \mu \mathrm{g}$ hygromycin $\mathrm{ml}^{-1}$. Plasmid-transformed yeast cells were grown throughout, for maintenance or for experimental purposes, in the relevant medium selective for the plasmid.

Growth conditions and toxicity assays. Organisms were maintained either in liquid YEPD medium or, where specified, in YNB medium supplemented with the appropriate amino acids or nucleic acid bases (Ausubel et al., 2007). The same media were used for preparation of experimental cultures, by subculture from stationaryphase culture and growth to mid-/late-exponential phase $\left(\mathrm{OD}_{600}\right.$ 2.0) at $30{ }^{\circ} \mathrm{C}, 120$ r.p.m. (Bishop et al., 2007). Growth in the broth media after addition of $\mathrm{Cu}\left(\mathrm{NO}_{3}\right)_{2}$ or paraquat (from filter-sterilized stock solutions) was followed at $\mathrm{OD}_{600}$ in $300 \mu \mathrm{l}$ volumes in 48 -well plates (Greiner Bio-One) incubated with shaking in a BioTek Powerwave microplate spectrophotometer (Smith et al., 2007). For qualitative viability assays on solid medium, dilution series from experimental cultures adjusted to $\mathrm{OD}_{600} \sim 2.0,0.2,0.02,0.002$ and 
0.0002 were spotted $(8 \mu \mathrm{l})$ onto medium solidified with agar $(1.6 \%$, $\mathrm{w} / \mathrm{v})$ and supplemented as specified. An L-MetO supplement containing a mixture of $\mathrm{R}$ and $\mathrm{S}$ MetO isomers was obtained from Sigma-Aldrich. Quantitative viability tests on solid medium were based on colony forming ability, as described previously (Smith et al., 2007).

Determination of $\mathrm{Cu}$ uptake. $\mathrm{Cu}\left(\mathrm{NO}_{3}\right)_{2}$ was added to experimental cultures $\left(\mathrm{OD}_{600} \sim 2.0\right)$ to a final concentration of $3 \mathrm{mM}$ and, after $20 \mathrm{~min}$ incubation, cells $(25 \mathrm{ml}$ samples $)$ were harvested by centrifugation $\left(740 \mathrm{~g}, 5 \mathrm{~min}\right.$ ). Control incubations at $4{ }^{\circ} \mathrm{C}$ were set up in parallel to enable discrimination of $\mathrm{Cu}$ that was passively bound to cells (Avery et al., 1996; Lin \& Kosman, 1990). For analysis by atomic absorption spectrophotometry (AAS), cell digests were prepared with $\mathrm{HNO}_{3}$ as described previously (Avery et al., 1996). Samples were filtered, diluted with $3 \mathrm{M} \mathrm{HNO}_{3}$, and analysed for $\mathrm{Cu}$ content using a SpectrAA 220FS atomic absorption spectrophotometer (Varian) that was calibrated with $0-0.5 \mathrm{mg} \mathrm{ml}^{-1}$ standard solutions of $\mathrm{Cu}\left(\mathrm{NO}_{3}\right)_{2}$. To support AAS measurements of $\mathrm{Cu}$ uptake, a colorimetric assay employing bathocuproine disulphonic acid (BCS) (Ramirez et al., 2005) was used to determine $\mathrm{Cu}$ concentrations in supernatants after removal of cells by centrifugation (see above). Cellular $\mathrm{Cu}$ uptake was determined by difference versus $\mathrm{Cu}$ determinations in parallel control flasks that lacked cells.

Microarray analysis. RNA was extracted from cells of experimental cultures $\left(\mathrm{OD}_{600} \sim 1.0\right)$ using the RNeasy Mini kit (Qiagen), after cell breakage with a mini-Beadbeater (Biospec Products) three times for $30 \mathrm{~s}$ interspersed with incubations on ice. Residual DNA was removed

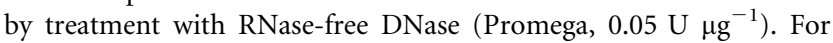
each yeast strain, RNA extracts from each of six replicate cultures were pooled into two samples (each comprising RNA from three replicate cultures), snap-frozen in liquid nitrogen and stored at $-20{ }^{\circ} \mathrm{C}$ until use. The integrity of RNA and cRNA was confirmed in all samples before analysis using an Agilent Bioanalyser. These analyses, RNA preparation, hybridizations to GeneChip Yeast Genome S98 Arrays (Affymetrix) and analysis with an Affymetrix GeneChip Reader were performed as a service by the NASC Affymetrix Service, University of Nottingham. Raw signal intensity data from hybridizations were normalized after removal of the highest and lowest $2 \%$ of signal values, and gene signals scoring 'marginal' or 'absent' were removed from the datasets (Payne et al., 2008). Genes showing $\geqslant 25 \%$ difference in signal intensities between replicate samples were also removed from the analysis. Fold up/downregulation values for individual transcripts were subsequently determined for mean signal values derived from the test (RNA from mutant) samples with reference to the corresponding control (wildtype) analyses.

Determination of individual transcript abundances. Cellular RNA was prepared as described above. The absence of protein or DNA contamination in RNA samples was confirmed according to $A_{260} / A_{280}$ ratios and standard PCR tests, respectively. For reversetranscription reactions, $1 \mu \mathrm{l}$ dNT mix $(10 \mathrm{mM}$ each of dATP, dCTP, dTTP and dGTP), $1 \mu \mathrm{l} 2.5 \mu \mathrm{g} \mu^{-1}$ oligo $(\mathrm{dT})_{20}$ primer (Invitrogen) and $1 \mu \mathrm{g}$ RNA template were combined and made up to $13 \mu \mathrm{l}$ with nuclease-free water. The mixture was heated to $65{ }^{\circ} \mathrm{C}$ for $5 \mathrm{~min}$, followed by incubation on ice for $\geqslant 1 \mathrm{~min}$. The contents of the tube were collected by brief centrifugation and $1 \mu \mathrm{l} 0.1 \mathrm{M} \mathrm{DTT}, 4 \mu \mathrm{l} 5 \times$ first strand buffer and $1 \mu$ l SuperScript III reverse transcriptase (200 $\mathrm{U}^{-1} \mathrm{l}^{-1}$, Invitrogen) were added. After incubation at $50{ }^{\circ} \mathrm{C}$ for $60 \mathrm{~min}$, the reaction was inactivated by heating to $70{ }^{\circ} \mathrm{C}$ for $15 \mathrm{~min}$. Residual RNA was removed by addition of $1 \mu \mathrm{l}$ (2 U) E. coli RNase $\mathrm{H}$ (Invitrogen) and incubation at $37{ }^{\circ} \mathrm{C}$ for $20 \mathrm{~min}$.

The relative abundance method was used to determine resultant cDNA levels by quantitative real-time (qRT)-PCR. For reactions,
$0.4 \mu \mathrm{M}$ each of gene-specific primers (HPLC purification scale, Sigma-Genosys), $2 \mu \mathrm{l}$ cDNA template from first-strand cDNA synthesis $\left(10^{-1}\right.$ dilution), and $2 \times$ QuantiTect SYBR Green PCR Master Mix were combined and made up to $25 \mu \mathrm{l}$ with RNase-free water in $0.2 \mathrm{ml}$ tubes (Stratagene). PCRs $\left[95{ }^{\circ} \mathrm{C}\right.$ for $10 \mathrm{~min}$, followed by $\left(95{ }^{\circ} \mathrm{C}\right.$ for $30 \mathrm{~s}, 55{ }^{\circ} \mathrm{C}$ for $1 \mathrm{~min}, 72{ }^{\circ} \mathrm{C}$ for $\left.30 \mathrm{~s}\right)$ for 40 cycles, followed by $95{ }^{\circ} \mathrm{C}$ for $1 \mathrm{~min}$, and $55{ }^{\circ} \mathrm{C}$ for $20.5 \mathrm{~min}$ ] were monitored using an MX4000 real-time PCR thermocycler (Stratagene). The results were normalized and analysed with the MX4000 software.

For semiquantitative RT-PCR, $10^{-1}, 10^{-2}$ and $10^{-3}$ dilutions of the cDNA were used as the template in PCRs $\left[95^{\circ} \mathrm{C}\right.$ for $1 \mathrm{~min}$, followed by $\left(95{ }^{\circ} \mathrm{C}\right.$ for $30 \mathrm{~s}, 55{ }^{\circ} \mathrm{C}$ for $1 \mathrm{~min}, 72{ }^{\circ} \mathrm{C}$ for $\left.1 \mathrm{~min}\right), 30$ cycles, followed by $72{ }^{\circ} \mathrm{C}$ for $10 \mathrm{~min}$ and then $4{ }^{\circ} \mathrm{C}$. The PCR products were examined by agarose gel electrophoresis and the intensities of the bands were compared between wild-type and mutant strains as specified, using template dilutions at which the reaction had not progressed to saturation. ACT1 was used as the reference mRNA.

Protein extraction and enzyme assays. Protein extracts were prepared as described elsewhere (Cashikar et al., 2005). Incubations were under nitrogen to protect FeS clusters. Protein extracts in supernatants were transferred to clean tubes and protein concentrations determined (Bradford, 1976). The assay of aconitase activity in protein extracts (from $2 \times 10^{8}$ cells) under nitrogen was performed as described elsewhere (Wallace et al., 2005). The change in absorbance was recorded at $1 \mathrm{~min}$ intervals for $8 \mathrm{~min}$ in UV cuvettes and the specific activity (per mg protein) calculated from the linear portion of the resultant plot. Isopropylmalate dehydratase (Leu1) activity was assayed as described by Kohlhaw (1988). The change in absorbance was recorded over $2 \mathrm{~min}$ following substrate addition, and the specific activity (per $\mathrm{mg}$ protein) calculated from the linear portion of the resultant plot.

In vivo ${ }^{\mathbf{5 5}} \mathbf{F e}$-labelling studies. Cultures $(25 \mathrm{ml})$ were grown overnight in YEPD to mid-exponential phase $\left(\mathrm{OD}_{600} \sim 0.5\right)$ in $125 \mathrm{ml}$ flasks, and $12.8 \mu \mathrm{Ci}(473.6 \mathrm{kBq})^{55} \mathrm{FeCl}_{3}$ (Perkin-Elmer) was added. For measurement of $\mathrm{FeS}$ cluster biosynthesis, cells were harvested after incubation for 1 or $2 \mathrm{~h}$ with ${ }^{55} \mathrm{Fe}$. For measurement of FeS cluster turnover, the ${ }^{55} \mathrm{Fe}$ pre-loaded cells were washed and resuspended in YEPD medium lacking ${ }^{55} \mathrm{Fe}$, and incubated for a further 1 or $2 \mathrm{~h}$ before harvesting. Protein extracts were prepared and immunoprecipitations with antibodies specific for Bio2p or Leulp (gifts from Roland Lill, University of Marburg) were performed as described elsewhere (Molik et al., 2007). Incorporated isotope was quantified in $1 \mathrm{ml}$ scintillation fluid (Emulsifier Safe, Perkin-Elmer) using a Packard Tri-Carb 2100TR liquid scintillation analyser.

\section{RESULTS}

\section{MSR activity sensitizes S. cerevisiae to copper}

During a study on the contribution of oxidative damage repair proteins to metal resistance in S. cerevisiae, we observed an unexpected $\mathrm{Cu}$-resistance phenotype in a $m \times r 1 \Delta / m x r 2 \Delta$ double mutant (hereafter referred to as $m x r \Delta$ ), which lacks MetO-reducing activity. Growth of this mxr $\Delta$ mutant (Kryukov et al., 2002) was only mildly affected by $\mathrm{Cu}\left(\mathrm{NO}_{3}\right)_{2}$ at a concentration which strongly inhibited growth of the wild-type (Fig. 1a). [Note that high $(\mathrm{mM}) \mathrm{Cu}$ concentrations are needed to observe growthinhibitory effects in rich medium (YEPD) such as that used here, as much of the added $\mathrm{Cu}$ is biologically unavailable in complexes with medium components (Avery et al., 1996; 
(a)

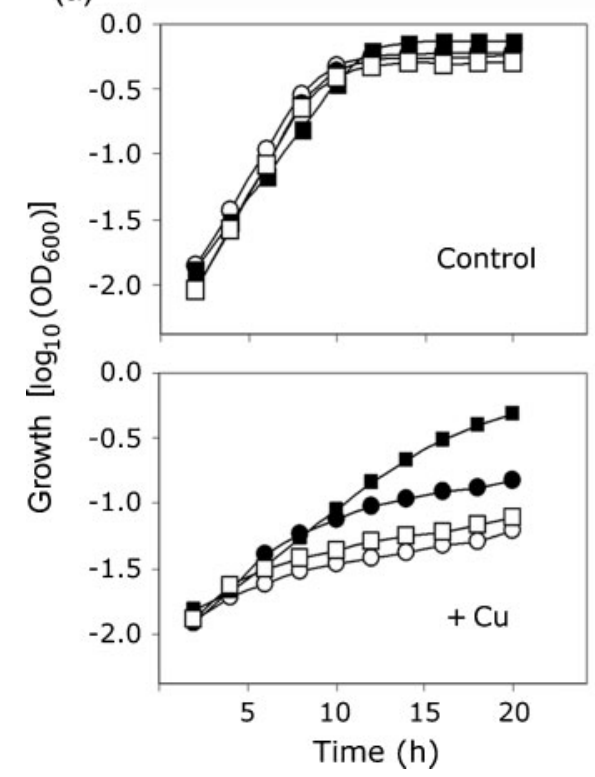

(b)
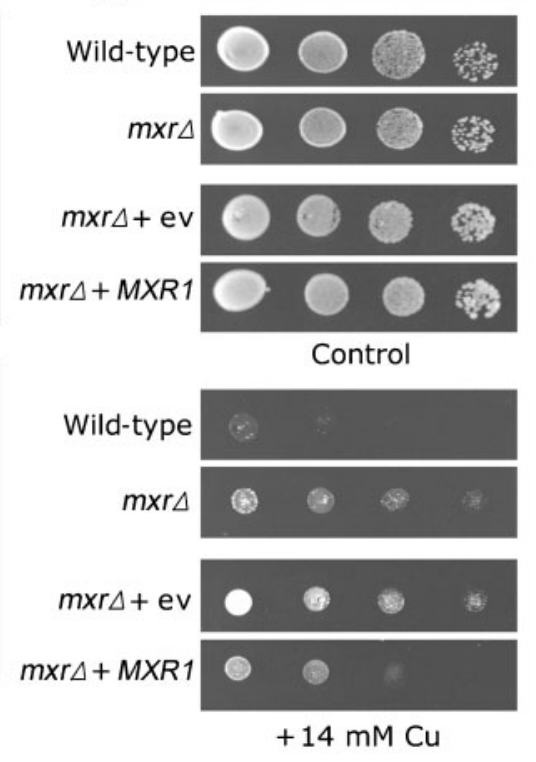

(c)
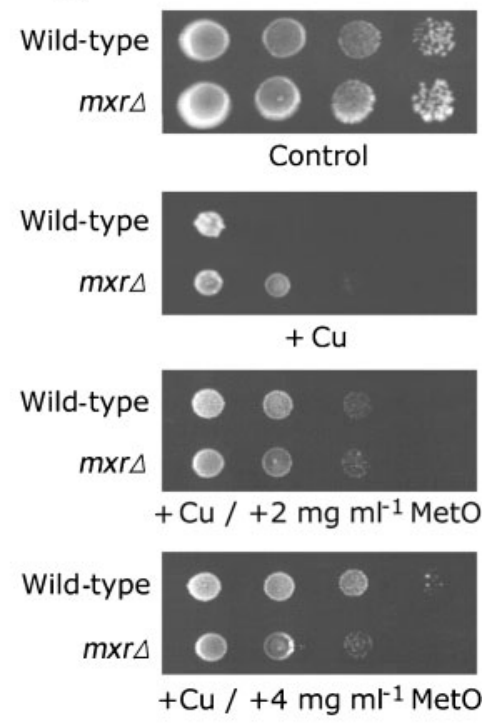

Fig. 1. MSR activity sensitizes YEPD-grown S. cerevisiae to copper. (a) Exponential-phase cells of the wild-type (BY4741) $(\bigcirc)$ or isogenic deletion strains $m \times r 1 \Delta(\mathbf{O}), \operatorname{mxr} 2 \Delta(\square)$ or $m x r 1 \Delta, m x r 2 \Delta$ (' $m x r \Delta$ ') ( $\square$ ) were inoculated into either unsupplemented YEPD broth (upper panel) or YEPD supplemented with $12 \mathrm{mM} \mathrm{Cu}\left(\mathrm{NO}_{3}\right)_{2}$ (lower panel) and incubated with shaking in a microplate spectrophotometer. (b, c) Exponential-phase cells were adjusted to $\mathrm{OD}_{600} \sim 2.0$. Tenfold dilution series were spotted (8 $\mu$ ) from left to right on YEPD agar supplemented or not supplemented with $14 \mathrm{mM} \mathrm{Cu}\left(\mathrm{NO}_{3}\right)_{2}$ and L-MetO, as indicated. '+ev', cells transformed with the single-copy 'empty' vector pRS315-hphN; '+MXR1', cells transformed with pRS315-hphN-MXR1. Media used for these transformed cells were additionally supplemented with $150 \mu \mathrm{g}$ hygromycin $\mathrm{ml}^{-1}$. Plates were observed after incubation at $30{ }^{\circ} \mathrm{C}$ for 4 days. Typical results from one of several independent experiments are shown.

Hughes \& Poole, 1991)]. The mxr $\Delta$ double mutant exhibited stronger $\mathrm{Cu}$ resistance than the $m \times r 1 \Delta$ and $m x r 2 \Delta$ single mutants, which are defective for reduction of different MetO stereoisomers. The $\mathrm{Cu}$ resistance of the $m x r \Delta$ mutant was evident also from growth on $\mathrm{Cu}$ supplemented agar (Fig. 1b), was suppressed by complementation with the MXR1 gene (Fig. 1b) and was confirmed in an independently constructed $m x r \Delta$ double mutant from our laboratory. The $\mathrm{Cu}$-resistance phenotype could be mimicked by growing wild-type cells in MetOsupplemented medium, whereas Met supplementation had no effect. MetO also abolished the relative resistance of the $m x r \Delta$ mutant (Fig. 1c). These data suggested that it is specifically the accumulation of MetO (rather than Met depletion or similar) in $m \times r \Delta$ cells that gives rise to $\mathrm{Cu}$ resistance. Yeast mutants lacking both MSRs have been reported previously to be sensitive to other pro-oxidants (Kryukov et al., 2002; Sumner et al., 2005). Those sensitivity phenotypes were confirmed during this study, indicating that the resistance phenotype was specific to $\mathrm{Cu}$.

\section{Decreased $\mathrm{Cu}$ uptake is not responsible for the $\mathrm{Cu}$ resistance of $\operatorname{mxr} \Delta$ cells}

To explain the $\mathrm{Cu}$ resistance of $m x r \Delta$ cells it was first suggested that, in the absence of MSR activity, oxidation of
Met residues in $\mathrm{Cu}$-uptake proteins causes inactivation and a decrease in $\mathrm{Cu}$ accumulation. The high-affinity $\mathrm{Cu}$ transporter Ctrlp is enriched in Met residues [proteins that interact with MSR are usually Met-rich (Alamuri \& Maier, 2006; Le et al., 2008)], some of which are required for $\mathrm{Cu}$ uptake (Puig et al., 2002). However, epistasis tests showed that MXR gene deletion conferred $\mathrm{Cu}$ resistance also in a ctr1 $\Delta$ background (data not shown), indicating that loss of Ctrlp activity is not the cause of $\mathrm{Cu}$ resistance in $m \times r \Delta$ cells. Loss of activity of Ctr2p (the putative low-affinity vacuolar $\mathrm{Cu}$ transporter) was also ruled out as, unlike $M X R$ gene deletion, CTR2 deletion did not improve growth on $\mathrm{Cu}$-supplemented agar. We also demonstrated with PCR that CTR3, which encodes a high-affinity $\mathrm{Cu}$ transporter, was disrupted by a Ty2 transposon insertion in the strains used here, as in most S. cerevisiae laboratory strains (Knight et al., 1996). Therefore, Ctr3p activity was not involved here. Epistasis experiments with mutants deficient in Fet4p, a low-affinity copper transporter, suggested that Fet4p inactivation partly contributes to $\mathrm{Cu}$ resistance in the $m x r \Delta$ mutant (see Supplementary Fig. S1). Moreover, Cuaccumulation tests indicated that an effect on $\mathrm{Cu}$ uptake was not the cause of $\mathrm{Cu}$ resistance in $m x r \Delta$ cells. According to two independent methods, calculated to exclude (Fig. 2a) or include (Fig. 2b) surface-associated $\mathrm{Cu}, \mathrm{Cu}$ accumulation was up to twofold higher in $m x r \Delta$ than in wild-type 

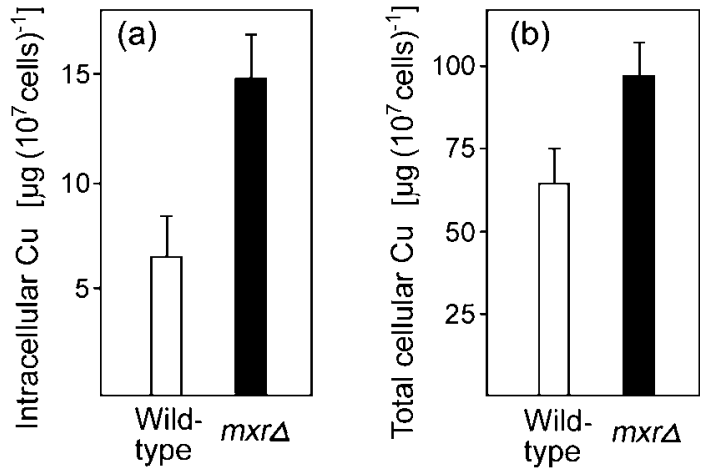

Fig. 2. Cellular $\mathrm{Cu}$ accumulation is increased in the $m x r \Delta$ mutant. Exponential-phase cells of the wild-type (white bars) or $m x r \Delta$ (black bars) strains were harvested after 20 min incubation in YEPD broth in the presence of $3 \mathrm{mM} \mathrm{Cu}\left(\mathrm{NO}_{3}\right)_{2}$. (a) Cellular $\mathrm{Cu}$ levels were determined by AAS, after washing of cells and digestion with $\mathrm{HNO}_{3}$. Surface-bound $\mathrm{Cu}$ was determined in parallel incubations at $4{ }^{\circ} \mathrm{C}$, and these values were subtracted from total cellular $\mathrm{Cu}$ to give intracellular $\mathrm{Cu}$ levels. (b) Total cellular $\mathrm{Cu}$ accumulation was determined according to BCSassisted measurement of $\mathrm{Cu}$ in medium supernatants. Mean \pm SEM data from three independent determinations are shown.

cells. It was inferred that for both $\mathrm{Cu}$ accumulation and $\mathrm{Cu}$ resistance to be elevated in $m x r \Delta$ cells, intracellular $\mathrm{Cu}$ must be less available to exert toxicity.

\section{Transcript levels of gene products mediating $\mathrm{Fe} / \mathrm{Cu}$ homeostasis and resistance are elevated in $m \times r \Delta$ versus wild-type cells}

In light of the above results, it was hypothesized that gene products which modulate the availability of free $\mathrm{Cu}$ in the cell are upregulated in $m x r \Delta$ versus wild-type cells. To test this, the transcriptomes of the two strains were compared. A preliminary microarray experiment in our laboratory indicated that $\sim 30$ genes were upregulated at least twofold in $m x r \Delta$ cells versus the wild-type (Supplementary Table S1). These included CCC2, which encodes a $\mathrm{Cu}$ transporter and, most strikingly, a set of genes of the iron regulon (Puig et al., 2005; Rutherford et al., 2003): FIT2, FIT3, ARN2, ARN3(SIT1), ARN4(ENB1) and TIS11. To explore this further, we analysed the more comprehensive microarray datasets produced elsewhere (Koc et al., 2004) for the same strain comparison. Those analyses distinguished 540 genes that were at least twofold upregulated in the mxr $\Delta$ mutant versus the wild-type. Again, Fe-regulon genes were among the most strongly upregulated, including FET3 ( 3.8-fold), FIT2 (3.0-fold), and ARN4 (2.7-fold) (Fig. 3a). Over half of the 10 most highly regulated Fe-regulon genes (Puig et al., 2005; Rutherford et al., 2003) were induced $\geqslant 1.5$-fold in the mxr $\Delta$ mutant. In addition, several gene functions that specifically modulate intracellular $\mathrm{Cu}$ availability were upregulated in $m x r \Delta$ cells, including CUP1 ( 2.0-fold), SOD1 (1.5-fold), FET3 (3.8-fold) and
CUP5 (2.6-fold) (Fig. 3b, c). Key transcriptomics data were validated with either qRT-PCR or semiquantitative RT-PCR. There were some quantitative differences in upregulation between the PCR-based and the microarray assays. Nonetheless, according to both, each of the four genes tested (CUP1, CUP5, FET3 and YHB1) was markedly upregulated in $m \times r \Delta$ versus wild-type cells (Fig. 3b, c).

It was reasoned that the upregulation of one or more of the identified $\mathrm{Cu}$-resistance determinants in the $m x r \Delta$ mutant could explain the elevated $\mathrm{Cu}$ resistance of these cells. Consistent with this, multicopy expression of SOD1 and FET3 was confirmed here to elevate the $\mathrm{Cu}$ resistance of wild-type S. cerevisiae (Supplementary Fig. S2). Conversely, CUP5 did not influence Cu resistance in our hands. SOD1, CUP1 and FET3 were selected initially for further study.

\section{The $\mathrm{Cu}$-binding Fet3 protein is required for the

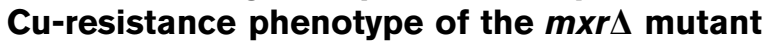

To test whether SOD1, CUP1 or FET3 was required for $\mathrm{Cu}$ resistance in the mxr $\Delta$ double mutant, in which they were each upregulated, these genes were deleted in the mxr $\Delta$ and wild-type backgrounds. Deletion of SOD1 did not alter the relative $\mathrm{Cu}$ resistances of the $m \times r \Delta$ and wild-type strains (data not shown), indicating that Sod1p is not required for

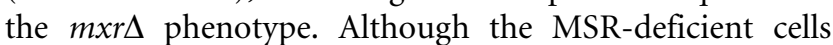
retained some $\mathrm{Cu}$ resistance following deletion of CUP1, the loss of resistance resulting from Cup1p deficiency was more marked for $m x r \Delta$ cells than for the wild-type. Thus, no colony formation by the wild-type was detectable at a $\mathrm{Cu}$ concentration yielding $\sim 40 \%$ viability of mxr $\Delta$ cells (Fig. $4 \mathrm{a}$ ), whereas cup $1 \Delta$ cells retained $>15 \%$ viability at a $\mathrm{Cu}$ concentration that yielded $<40 \%$ viability in mxr $\Delta /$ cup1s cells (Fig. 4b). Therefore, CUP1 upregulation in $m x r \Delta$ cells (above) may partially contribute to their $\mathrm{Cu}$ resistance. In contrast, FET3 was required for the phenotype. As expected (Stoj et al., 2007), FET3 deletion resulted in a sensitization to $\mathrm{Cu}$ in both the wild-type and the mxr $\Delta$ background (note the different $\mathrm{Cu}$ concentrations in Fig. 4c versus Fig. 4a). However, this sensitization was much greater in the mxr $\Delta$ mutant than in the wildtype. Put another way, an absence of MSR activity had the opposite effect on $\mathrm{Cu}$ resistance in the fet $3 \Delta$ background to that in the wild-type (Fig. $4 \mathrm{a}, \mathrm{c}$ ). The $\mathrm{Cu}$ sensitivity of $m x r \Delta /$ fet $3 \Delta$ cells relative to $f e t 3 \Delta$ cells was similar to that seen for other pro-oxidants in comparisons of mxr mutant and wild-type cells (Kryukov et al., 2002; Moskovitz et al., 1997; Sumner et al., 2005). The results indicated that the unexpected $\mathrm{Cu}$ resistance of $m \times r \Delta$ cells could be accounted for by the FET3 upregulation observed in this mutant. A partial role for CUP1 in the phenotype (above) was further supported by observations that removal of MSR activity in a cup $1 \Delta /$ fet $3 \Delta$ background caused a greater relative sensitization to $\mathrm{Cu}$ than occurred in a fet $3 \Delta$ background (Supplementary Fig. S3), but the more important role evident for FET3 provided the focus for subsequent experiments. 
(a)

\begin{tabular}{|c|c|c|c|}
\hline $\begin{array}{l}\text { Fe regulon genes } \\
\text { highly } \\
\text { upregulated by Fe } \\
\text { depletion (Puig et } \\
\text { al., 2005) }\end{array}$ & $\begin{array}{l}\text { Fold induction in } \\
m s r \Delta \text { versus wild- } \\
\text { type cells (Koc et } \\
\text { al., 2004) }\end{array}$ & $\begin{array}{c}\text { Fe regulon genes } \\
\text { highly } \\
\text { upregulated by } \\
\text { constitutive } A F T I \\
\text { activation } \\
\text { (Rutherford } \text { et al., } \\
2003 \text { ) }\end{array}$ & $\begin{array}{c}\text { Fold induction in } \\
m s r \Delta \text { versus wild- } \\
\text { type cells (Koc et } \\
\text { al., 2004) }\end{array}$ \\
\hline FIT3 & 1.6 & FIT3 & 1.6 \\
\hline FIT2 & 3.0 & FIT2 & 3.0 \\
\hline$A R N 2(T A F 1)$ & 1.5 & FET3 & 3.8 \\
\hline ARNI & 2.0 & FITl & 1.0 \\
\hline FITI & 1.0 & YOR $387 C$ & 0.9 \\
\hline FET3 & 3.8 & $A R N 4$ (ENBI) & 2.7 \\
\hline ARN3 (SIT1) & 1.7 & ARN3 (SIT1) & 1.7 \\
\hline TIS11 (CTH2) & 0.9 & TISII (CTH2) & 0.9 \\
\hline FTRI & 1.3 & FTRI & 1.3 \\
\hline ARN4 (ENBI) & 2.7 & FRE2 & 0.6 \\
\hline
\end{tabular}

(b)

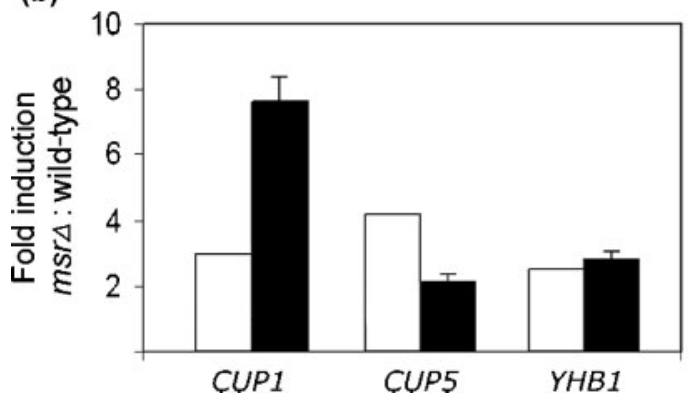

(c)

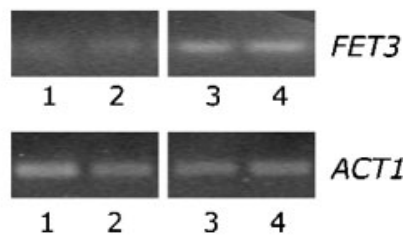

\section{FeS cluster-dependent functions are deficient in the mxr $\Delta$ mutant}

FET3 transcription is known to be under the regulation of the Aft2 and, in particular, the Aft1 transcription factors. These have overlapping roles in the regulation of iron utilization and homeostasis (Rutherford et al., 2003, 2005). The possible activation of Aft 1 and/or Aft 2 in $m x r \Delta$ cells was suggested by the upregulation not only of FET3 (and associated $\mathrm{Cu}$ resistance) but also of other Aft-dependent genes (Rutherford et al., 2003) such as ARN1, ARN4, FIT2 and FRE6 (Fig. 3a). We expressed an AFT1- ${ }^{\text {up }}$ allele, which produces constitutively active Aftlp (Yamaguchi-Iwai et al., 1995). AFT1- ${ }^{\text {up }}$ expression in wild-type cells incubated in YEPD mimicked the phenotype of $\mathrm{Cu}$ resistance seen in $m x r \Delta$ cells (Fig. 5). In contrast, AFT1- $1^{\text {up }}$ expression in the $m x r \Delta$ mutant had no further effect on $\mathrm{Cu}$ resistance. The results were consistent with $\mathrm{Aft}$ activation determining $\mathrm{Cu}$ resistance in $m x r \Delta$ cells (see Fig. 6 for scheme).

Aft1p (and consequently FET3) is usually activated under Fe-limited conditions. This activation has been traced
Fig. 3. Upregulation of Fe-regulon and $\mathrm{Cu}-$ resistance genes in the $m x r \Delta$ mutant. (a) The table lists the 10 yeast Fe-regulon genes identified previously as the most highly upregulated in response to Fe depletion (Puig et al., 2005), or during constitutive Fe-regulon activation via AFT1-1 up expression (Rutherford et al., 2003). The genes are listed in order with the most highly upregulated first. The data in columns 2 and 4 indicate the $m x r \Delta$ : wild-type expression ratio for the listed genes, derived from other published microarray datasets (Koc et al., 2004). (b) Levels of CUP1, CUP5 and YHB1 upregulation in $m x r \Delta$ versus wild-type cells were derived from microarray data (Koc et al., 2004) (white bars) and from transcript-specific qRT-PCR analyses (black bars). The latter data were normalized against ACT1 mRNA determinations in the same samples, and then against the corresponding determinations for wild-type samples to yield values for upregulation. Mean data \pm SEM from two independent biological replicates are shown. (c) FET3 transcript levels were examined with semiquantitative RT-PCR [this was deemed adequate for FET3 expression as these analyses were performed later in the study, when microarray and phenotypic (below) studies had already substantiated a role for FET3]. Lanes 1 and 2, replicate wild-type samples; lanes 3 and 4 , replicate $m \times r \Delta$ samples. The microarray data for FET3 (not shown) indicated a 3.8-fold upregulation in $m x r \Delta$ versus wild-type cells. largely to defective FeS cluster biogenesis in mitochondria (Chen et al., 2004; Rutherford et al., 2005). Accordingly, the transcriptomic responses to FeS biogenesis defects and Aft1 activation are strikingly similar (Hausmann et al., 2008). To test for FeS cluster defects in $m x r \Delta$ cells, the activities of the $[4 \mathrm{Fe}-4 \mathrm{~S}]$-containing enzymes aconitase (Acolp) and isopropylmalate isomerase (Leulp) were assayed. Aconitase specific activity was reproducibly $\sim 30 \%$ lower in protein extracts from $m x r \Delta$ cells than in extracts from wild-type cells (Fig. 7a). This activity defect was despite an approximately sixfold higher level of ACO1 mRNA in $m x r \Delta$ cells (Koc et al., 2004). In conjunction with a $>50 \%$ decrease in Leulp activity in the $m x r \Delta$ mutant (Fig. 7a), these data supported the hypothesis that $m x r \Delta$ cells have a FeS cluster defect.

If, as inferred, FeS cluster defects in $m x r \Delta$ cells are the cause of FET3 upregulation and $\mathrm{Cu}$ resistance (Fig. 6), then it should be possible to mimic these phenotypes by manipulating the integrity of FeS clusters. This was tested by creating conditions conducive to FeS cluster degradation, achieved using a sod2s mutant defective for Mn- 

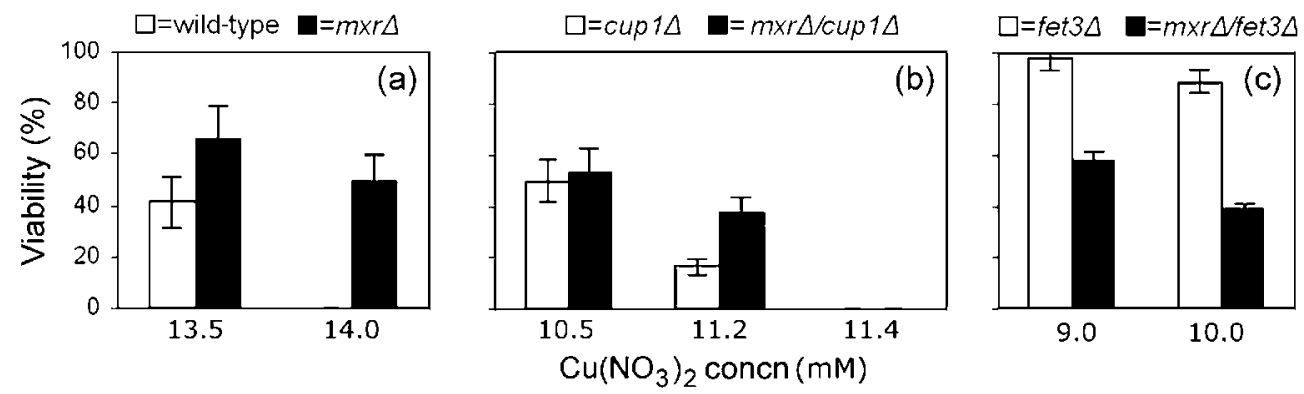

Fig. 4. FET3 is required for the $\mathrm{Cu}$ resistance of $m x r \Delta$ cells. Exponential-phase cells $\left(\mathrm{OD}_{600} \sim 2.0\right)$ that were either wild-type (white bars) or deleted for the MXR genes (black bars) were washed, diluted and spread-plated onto YEPD agar supplemented or not supplemented with the specified concentrations of $\mathrm{Cu}\left(\mathrm{NO}_{3}\right)_{2}$. Colonies were enumerated after incubation for 4 days at $30{ }^{\circ} \mathrm{C}$ and percentage viability was calculated with reference to growth on control plates lacking $\mathrm{Cu}$. The strains tested were: (a) S. cerevisiae BY4741 (wild-type) (white bars) and $m x r \Delta$ (black bars); (b) cup $1 \Delta$ (white bars) and $m x r \Delta / c u p 1 \Delta$ (black bars); and (c) fet $3 \Delta$ (white bars) and $m x r \Delta /$ fet3 $\Delta$ (black bars). Mean \pm SEM data from three independent determinations are shown.

superoxide dismutase activity; like the process of $\mathrm{FeS}$ biosynthesis, Sod2p localizes to mitochondria, where it scavenges superoxide radicals, which are major antagonists of FeS cluster activity. Thus, Sod $2 p$ activity protects the integrity of mitochondrial $\mathrm{FeS}$ clusters (Irazusta et al., 2006; Strain et al., 1998). Consistent with this, the FET3 gene appeared to be upregulated in $\operatorname{sod} 2 \Delta$ cells relative to the wild-type (Fig. $7 \mathrm{~b}$ ). Furthermore, the sod $2 \Delta$ mutant reproducibly showed a slightly higher $\mathrm{Cu}$ resistance than

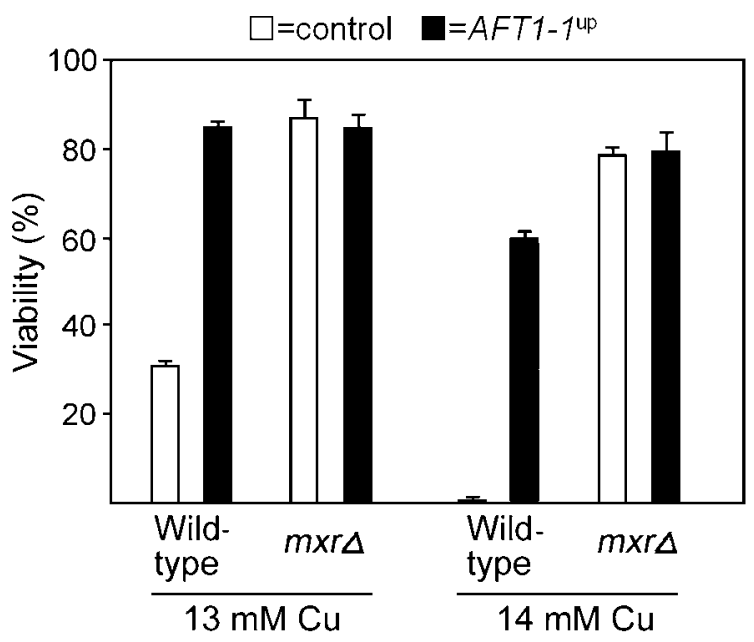

Fig. 5. Constitutive activation of Aft $1 p$ mimics the Cu resistance of $m x r \Delta$ cells in YEPD medium. Exponential-phase wild-type and $m x r \Delta$ cells transformed with either pRS315-hphNT1-AFT1-1 up (black bars) or the empty vector pRS315-hphNT1 (white bars) were spread-plated onto YEPD agar supplemented with 13 or $14 \mathrm{mM} \mathrm{Cu}\left(\mathrm{NO}_{3}\right)_{2}$, as indicated. Viability (colony formation) was determined after incubation for 4 days at $30{ }^{\circ} \mathrm{C}$, and percentage viability was calculated with reference to growth on control plates lacking $\mathrm{Cu}$. Mean \pm SEM data from three independent determinations are shown. the wild-type in YEPD medium (Fig. 7c). This phenotype was similar, albeit less marked, to the phenotype of $m \times r \Delta$ cells described above. To test whether FET3 was required for $\mathrm{Cu}$ resistance of the sod $2 \Delta$ mutant, as in the $m x r \Delta$ mutant (Fig. 4a, c), the effect of SOD2 deletion was examined also in a fet $3 \Delta$ background. Fet3p deficiency abolished the slight $\mathrm{Cu}$ resistance otherwise associated with SOD2 deletion (Fig. 7c, d). Thus, the FET3-dependent $\mathrm{Cu}$ resistance seen in $m \times r \Delta$ cells could be reproduced, albeit less strikingly, in a mutant known to be limited for FeS cluster integrity.

\section{Turnover of [4Fe-4S] clusters is increased in the mxr $\Delta$ mutant}

It was speculated that the FeS cluster defect in $m x r \Delta$ cells was due either to an increased rate of FeS cluster turnover or to decreased FeS cluster biosynthesis. To resolve these possibilities, the association of radiolabelled ${ }^{55} \mathrm{Fe}$ with $\mathrm{FeS}$ proteins was measured. This was accomplished by

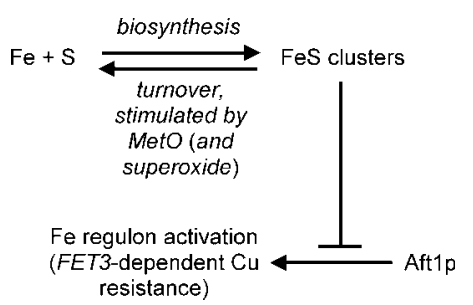

Fig. 6. Proposed scheme explaining the $\mathrm{Cu}$ resistance of $m x r \Delta$ cells. The relative $\mathrm{Cu}$ resistance of the mxr $\Delta$ mutant was dependent on FET3, a component of the Fe regulon of yeast that is activated by Aft $1 p$. Aft $1 p$ is responsive to low FeS-cluster status in cells. It is proposed in this paper that high MetO levels (like high superoxide levels) stimulate the turnover of FeS clusters, so activating Aft $1 \mathrm{p}$ and inducing FET3-dependent $\mathrm{Cu}$ resistance. 
(a)

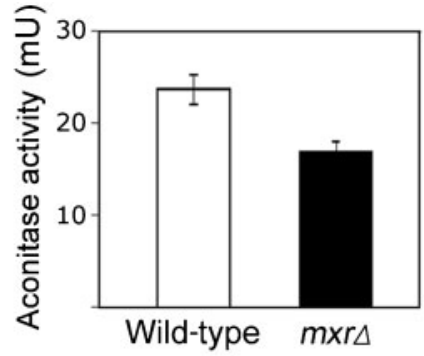

(b)

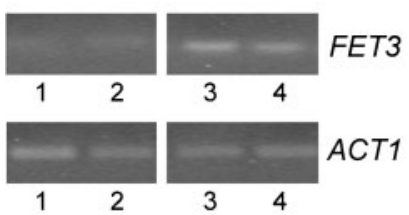

(c)

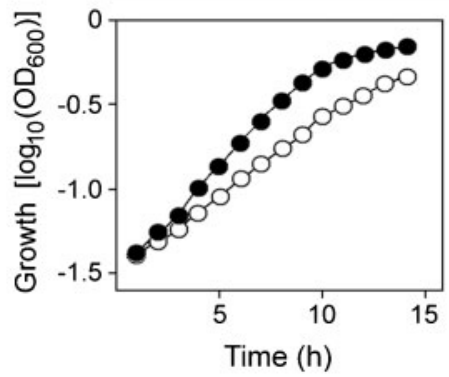

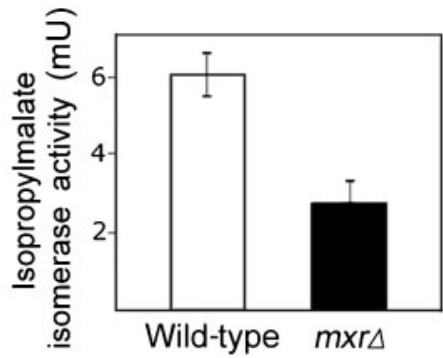

(d)

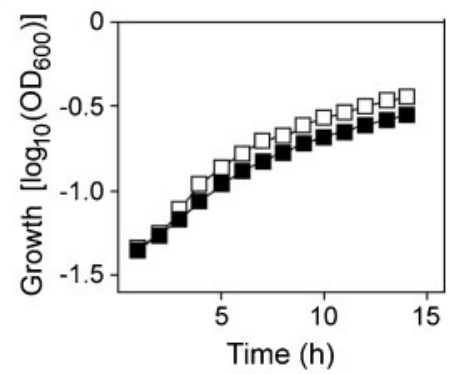

Fig. 7. FeS-protein defects in the $m x r \Delta$ mutant, and mimicry of the $m x r \Delta$ phenotype by SOD2 deletion. (a) Aconitase and isopropylmalate isomerase activities were determined in protein extracts from exponential-phase wild-type and $m x r \Delta$ cells. Mean \pm SEM data from three independent determinations are shown. (b) Levels of FET3 and ACT1 mRNA were determined in RNA extracts from exponential-phase wild-type or sod2 $\Delta$ cells, using semiquantitative RT-PCR. Lanes 1 and 2, replicate wildtype samples; lanes 3 and 4, replicate sod2 $\Delta$ samples. [Note that the controls (lanes 1 and 2) are the same as in Fig. 3(c), as these analyses were part of the same experiment.] (c) Growth of wild-type ( $\bigcirc)$ and sod2 $\Delta$ ( $)$ cells was monitored in YEPD medium supplemented with $10 \mathrm{mM} \mathrm{Cu}\left(\mathrm{NO}_{3}\right)_{2}$, with shaking in a microplate spectrophotometer. (d) Growth of fet3 $\Delta$ ( $\square$ ) or fet $3 \Delta / \operatorname{sod} 2 \Delta(\boldsymbol{\square})$ mutants in YEPD medium supplemented with $10 \mathrm{mM} \mathrm{Cu}\left(\mathrm{NO}_{3}\right)_{2}$. Note that there were no growth differences between strains in control YEPD medium lacking $\mathrm{Cu}\left(\mathrm{NO}_{3}\right)_{2}$ (results not shown). Typical data from one of at least three independent experiments are shown in each case. Absolute measurements varied by $>10 \%$ between certain replicate experiments, but the effects of the gene deletions relative to wild-type varied by $<10 \%$. The growth effects described in (c) and (d) were relatively small, but reproducible in every experiment.

immunoprecipitation of $\mathrm{FeS}$ proteins of interest from cells after incubation with ${ }^{55} \mathrm{FeCl}_{3}$, and quantification of isotope in the immunoprecipitates. To distinguish FeS biosynthesis from FeS turnover, FeS proteins were immunoprecipitated from cells both during ${ }^{55} \mathrm{Fe}$ incorporation (biosynthesis) and during a period after transferring ${ }^{55} \mathrm{Fe}$-loaded cells to ${ }^{55} \mathrm{Fe}$-free medium (turnover). First, we performed immunoprecipitations with the mitochondrial FeS protein biotin synthase (Bio2p). Analysis of immunoprecipitated protein with SDS-PAGE confirmed that the Bio2 protein levels in $m x r \Delta$ and wild-type strains were similar (Supplementary Fig. S4). The incorporation of ${ }^{55} \mathrm{Fe}$ into Bio2p after $1 \mathrm{~h}$ was decreased by about one-third in the $m x r \Delta$ mutant (Fig. 8a), possibly suggesting a defect in FeS biosynthesis. A comparable difference was also observed after $2 \mathrm{~h}$ of ${ }^{55} \mathrm{Fe}$ incorporation (Supplementary Fig. S5). However, analyses of ${ }^{55} \mathrm{FeS}$ turnover indicated that a similar proportion $(\sim 30 \%)$ of the Bio2p-associated ${ }^{55} \mathrm{Fe}$ of wild-type cells was lost within $1 \mathrm{~h}$ in ${ }^{55} \mathrm{Fe}$-free medium, whereas the labelled Bio2p was stable in mxr cells (Fig. 8a). These data may be rationalized by the fact that biotin synthases contain a [2Fe-2S] cluster in addition to the oxygen-labile [4Fe-4S] cluster (Jarrett, 2005). Previous data indicate that the additional $\sim 30 \%$ of ${ }^{55} \mathrm{Fe}$ incorporated into (and lost from) Bio2p in wild-type cells, observed here, could correspond to the labile [4Fe-4S] cluster (Mühlenhoff et al., 2007). If so, then our data suggest that there is no detectable incorporation of ${ }^{55} \mathrm{Fe}$ into the [4Fe-4S] cluster of Bio2p in $m x r \Delta$ cells, consistent with a [4Fe-4S]-specific biosynthesis defect in the mxr $\Delta$ mutant. However, considering the rapid turnover of ${ }^{55} \mathrm{Fe}$ in Bio2 $p$ measured in the wild-type, our data also leave open the possibility that the inability to detect ${ }^{55} \mathrm{Fe}$ incorporation to Bio2p of $m x r \Delta$ cells results from a significantly elevated $[4 \mathrm{Fe}-4 \mathrm{~S}]$ turnover rate (i.e. clusters are turned over at least as fast as they are synthesized).

To help resolve these possibilities, we also performed ${ }^{55} \mathrm{Fe}$ labelling and immunoprecipitation with Leulp. Unlike Bio2p, Leu1p contains only a [4Fe-4S] cluster. Moreover, we considered that the cytosolic localization of Leulp should help to give slower FeS turnover rates than those suggested above for mitochondrial Bio2p, mitochondria being the major source of ROS in respiring cells. This was 


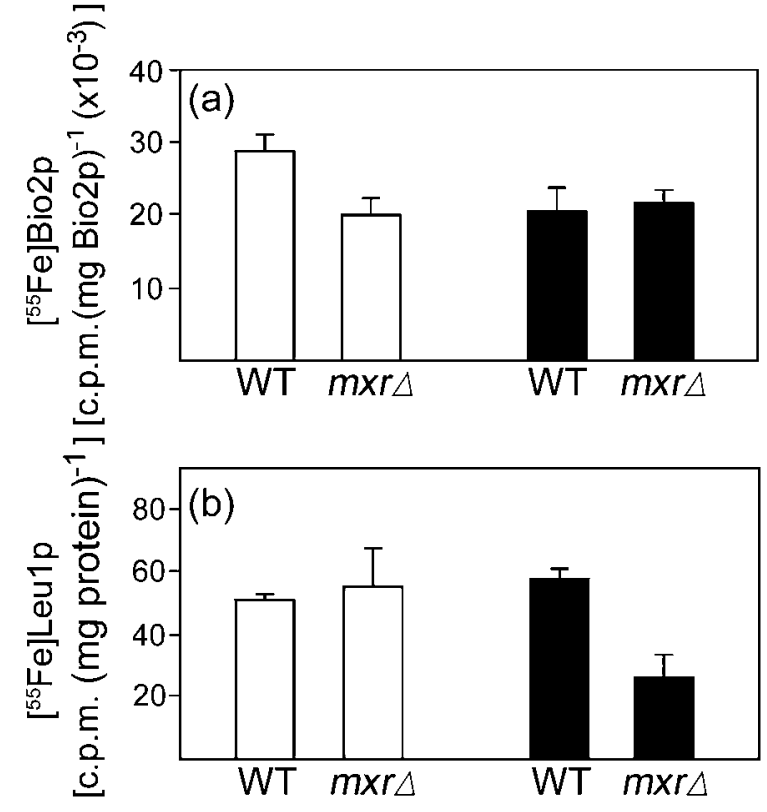

Fig. 8. Determination of ${ }^{55} \mathrm{Fe}$ incorporation into $\mathrm{FeS}$ proteins. Exponential-phase wild-type or $m x r \Delta$ cells were incubated for up to $2 \mathrm{~h}$ in YEPD supplemented with $12.8 \mu_{\mathrm{Ci} \mathrm{ml}}^{-1}\left(473.6 \mathrm{kBq} \mathrm{ml}^{-1}\right)$ ${ }^{55} \mathrm{FeCl}_{3}$, before protein extracts were prepared and immunoprecipitations performed with anti-Bio2 $p$ (a) or anti-Leu1p (b) antibodies. ${ }^{55} \mathrm{Fe}$ levels in immunoprecipitates prepared from $0.5 \mathrm{mg}$ protein extract were determined by scintillation counting. The data shown are for immunopreciptates obtained after $1 \mathrm{~h}$ labelling in ${ }^{55} \mathrm{Fe}$-supplemented medium (white bars), or after $1 \mathrm{~h}$ labelling followed by $1 \mathrm{~h}$ incubation in ${ }^{55} \mathrm{Fe}$-free medium (black bars). (Note that similar data were obtained with samples obtained after $2 \mathrm{~h}$ incubations; Supplementary Fig. S5.) The data are means $\pm S E M$ from three replicate determinations, and typical results from one of at least two independent experiments are shown. WT, wild-type.

borne out by the data as, unlike with Bio2p (Fig. 8a), no turnover of ${ }^{55} \mathrm{Fe}$-labelled Leu1p was detected within $1 \mathrm{~h}$ of transferring labelled wild-type cells to ${ }^{55} \mathrm{Fe}$-free medium (Fig. 8b). In contrast, $m x r \Delta$ cells treated in the same way exhibited a $>50 \%$ decrease in ${ }^{55} \mathrm{Fe}$-labelled Leulp. There was no significant difference in the incorporation of label into Leulp of $m x r \Delta$ and wild-type cells. The data collectively indicate a [4Fe-4S] cluster defect in $m x r \Delta$ cells, which, at least in the case of Leulp, can be attributed to a higher rate of $[4 \mathrm{Fe}-4 \mathrm{~S}]$ turnover than in wild-type cells.

\section{DISCUSSION}

This study reveals a novel role for the MSR proteins of $S$. cerevisiae in helping to preserve the function of cellular FeS clusters. Previous work has established an antioxidant function for the MSR enzymes, methionines being especially susceptible to oxidation compared with other amino acids. Such MSR activity has been proposed to protect against the damaging effects of $\mathrm{MetO}$ on protein function, to support ROS scavenging via reduced Met, and to act as a mechanism for regulating protein activity (Moskovitz, 2005; Oien \& Moskovitz, 2008). However, a link to FeS protein function has not previously been reported. This is an important discovery, as the requirement to maintain the integrity of essential FeS proteins is a key challenge to organisms with an aerobic lifestyle (Imlay, 2006). Therefore, the ubiquitous MSR proteins could be an important factor facilitating aerobicity.

The finding that the deletion of both MXR1 and, to a lesser extent, of MXR2 contributed to the Cu-resistance phenotype of the $m x r \Delta$ double mutant was consistent with the relative contributions of these proteins to other phenotypes in yeast (Koc et al., 2004; Kryukov et al., 2002; Sumner et al., 2005). This indicates that both the $\mathrm{S}$ and $\mathrm{R}$ stereoisomers of MetO are a factor in the FeS cluster defects that led to $\mathrm{Cu}$ resistance. The $\mathrm{Cu}$-resistance phenotype of $m x r \Delta$ cells occurred despite an increased level of $\mathrm{Cu}$ accumulation. Therefore, $\mathrm{Cu}$ must be less available to exert toxicity in the $m x r \Delta$ mutant, as borne out by the upregulation of a number of $\mathrm{Cu}$-binding proteins in this strain, in particular Fet3p. FET3 transcription is principally under Aftlp control (Courel et al., 2005; Rutherford et al., 2003; YamaguchiIwai et al., 1995), and the microarray and AFT1-1 ${ }^{\text {up }}$ expression evidence was consistent with Aft1p dependency here (Fig. 6). The low-affinity $\mathrm{Cu}$ transporter Fet4p has also been reported to be under Aftlp control (Waters \& Eide, 2002), and is upregulated approximately twofold in the $m x r \Delta$ mutant (Koc et al., 2004). Therefore, Fet4p could account for the elevated $\mathrm{Cu}$ uptake of this strain.

The protection of both mitochondrial (Aco1p, Bio2p) and cytosolic (Leulp) FeS proteins by MSR activity indicated here suggests that the MSRs localize to both of these subcellular compartments. Mammalian MsrA and MsrB proteins have been localized variously to mitochondria, the cytosol and nucleus (Kim \& Gladyshev, 2004). To our knowledge, MSR localization has not been examined directly in yeast. Global protein localization studies (Huh et al., 2003; Kumar et al., 2002) indicate that MsrA (encoded by MXR1) occurs in the cytosol and nucleus (there are no data for yeast MsrB). Moreover, the Predotar tool for identification of $\mathrm{N}$-terminal targeting sequences (Small et al., 2004) gives an $81 \%$ probability that the yeast MsrB (encoded by MXR2) localizes to mitochondria (no localization sequence is predicted for MsrA). A mammalian mitochondrion-targeted MsrB protein is sufficient to rescue a yeast $m x r \Delta$ double mutant, indicating the importance of mitochondrial MetO reduction (Kim \& Gladyshev, 2004). These predictions imply that MsrA protects $\mathrm{FeS}$ cluster integrity primarily in cytosolic and nuclear proteins, and $\mathrm{MsrB}$ in mitochondrial FeS proteins [including the FeS-related signal that is exported to Aft1p (Rutherford et al., 2005)]. The question has been posed elsewhere (Moskovitz, 2005), what is the dominant role of mitochondrial MSR activity? The present study reveals that preservation of $\mathrm{FeS}$ cluster function, at the site of FeS biosynthesis, could be the answer. 
One question arising from our study is how does MSR activity protect FeS-cluster function? FeS-cluster deficiencies can result from depletion of mitochondrial Fe (Li \& Kaplan, 2004). However, the possibility that a mxr $\Delta$ defect in mitochondrial Fe accumulation is responsible is unlikely, as Fe supplementation in the medium up to $3 \mathrm{mM}$ does not alter the relative $\mathrm{Cu}$ sensitivities of $m x r \Delta$ and wild-type strains (T. Sideri and S. V. Avery, unpublished data). Furthermore, our ${ }^{55} \mathrm{Fe}$-labelling studies suggested that the FeS defect in mxr $\Delta$ cells is primarily attributable to an enhanced FeS-turnover rate rather than decreased FeS biosynthesis, substantiating that $\mathrm{Fe}$ availability is not the primary cause.

It is unlikely that the FeS defect is due to some generic antioxidant activity of MSRs, as other antioxidant genes in yeast do not yield a $\mathrm{Cu}$-resistance phenotype upon deletion (Avery, 2001; Jo et al., 2008). One exception is SOD2, as corroborated here. Sod2p has a specific role in preserving mitochondrial FeS-cluster integrity by scavenging mitochondrial superoxide radicals that are primary antagonists of FeS function (Irazusta et al., 2006). It has been proposed that MSRs indirectly enhance scavenging of free radicals such as superoxide by regenerating reduced Met residues that act as antioxidants (Levine et al., 1996; Melkani et al., 2006). However, Met depletion was not responsible for the $m x r \Delta$ phenotype, as Met supplementation of the medium did not suppress $\mathrm{Cu}$ resistance. In contrast, the addition of MetO to wild-type cultures mimicked the phenotype, indicating that Met oxidation (rather than depletion) was causative. A number of proteins are reported to be inactivated by Met oxidation (Alamuri \& Maier, 2006; Ezraty et al., 2004; Sun et al., 1999). However, FeS proteins are not among those characterized. Furthermore, none of the MSR-interacting proteins that have been identified in bacteria (Alamuri \& Maier, 2006) or in protein-interaction studies with yeast (http://www.yeastgenome.org/) are FeS proteins. Bacterial MSR is reported to bind proteins with Met contents approximately twofold higher than average (Alamuri \& Maier, 2006), whereas the average Met content of yeast $\mathrm{FeS}$ proteins is only slightly higher (at $2.6 \%$ ) than that of all yeast proteins $(2.3 \%)$.

If the yeast MSRs do not interact directly with FeS proteins, they may modulate the activities of proteins that themselves influence $\mathrm{FeS}$ function. Met oxidation can cause conformational changes in proteins, as MetO is more hydrophilic than Met (Moskovitz, 2005). The helix-breaking character of MetO is thought to be exploited in regulation and signalling (Bigelow \& Squier, 2005; Ciorba et al., 1997). It should also be noted that MetO may initiate other oxidative reactions that themselves exert damage. For example, oxidation of the Met-35 residue of $\beta$-amyloid peptides is thought to be linked to catalysis of free radical production (Pogocki, 2003). Yeasts lacking MsrA exhibit increased levels of protein carbonylation (Oien \& Moskovitz, 2007), a marker of broader oxidative protein damage than solely Met oxidation (Sumner et al., 2005). Furthermore, a general decrease in mitochondrial ROS production and oxidative damage in calorie-restricted rats has been linked specifically to methionine (and therefore presumably MetO) restriction (Sanz et al., 2006). Although these studies did not examine FeS-cluster function, they have highlighted how Met oxidation may trigger a cascade of oxidative events leading to the phenotype. Considering that FeS clusters are major targets of superoxide action (Imlay, 2006), as underscored here with Sod2p manipulations, any catalysis of (mitochondrial) superoxide generation that is associated with MetO formation (Pogocki, 2003) could explain the FeS defects in mxr $\Delta$ cells.

A relationship between cellular MSR activity and FeS-cluster function, revealed here, could be widely conserved. Both types of function are found among almost all organisms, and both have ancient origins (Delaye et al., 2007; Imlay, 2006). Furthermore, defects in both are associated with degeneration and disease. For example, aberrant Fe homeostasis (e.g. due to FeS-cluster defects) contributes to the ageing process (Atamna et al., 2002), while a role for MSR activity in extending lifespan is conserved across different organisms (Koc et al., 2004). In addition, a major hallmark of Friedreich's ataxia is decreased activity of FeS enzymes (Shan et al., 2007), and ataxia symptoms have been reported in MsrA-deficient mice (Moskovitz et al., 2001). While such disease states were not a focus of this study, our results have revealed a relationship that contributes to our understanding of ROS-related degeneration and the sustenance of FeScluster activity in aerobic settings.

\section{ACKNOWLEDGEMENTS}

This work was supported by a grant from the National Institutes of Health (R01 GM57945). We thank Roland Lill (University of Marburg) for his kind gifts of anti-Bio2p and anti-Leulp antibodies. We also thank Victor Gladyshev (University of Nebraska) for sharing his mxr $\Delta$ double mutant, Jerry Kaplan (University of Utah) for plasmid pRS313-AFT1-1 ${ }^{\text {up }}$, and Valeria Culotta (Johns Hopkins University) for plasmid pJS411. We are grateful for expert technical assistance from Lee Shunburne.

\section{REFERENCES}

Alamuri, P. \& Maier, R. J. (2006). Methionine sulfoxide reductase in Helicobacter pylori: interaction with methionine-rich proteins and stress-induced expression. J Bacteriol 188, 5839-5850.

Amberg, D. C., Burke, D. J. \& Strathern, J. N. (2005). Methods in Yeast Genetics. A Cold Spring Harbor Laboratory Manual. Cold Spring Harbor, NY: Cold Spring Harbor Laboratory.

Askwith, C. \& Kaplan, J. (1998). Iron and copper transport in yeast and its relevance to human disease. Trends Biochem Sci 23, 135-138.

Atamna, H., Walter, P. B. \& Ames, B. N. (2002). The role of heme and iron-sulfur clusters in mitochondrial biogenesis, maintenance, and decay with age. Arch Biochem Biophys 397, 345-353.

Ausubel, F. M., Brent, R., Kingston, R. E., Moore, D. D., Seidman, J. G. \& Struhl, K. (2007). Current Protocols in Molecular Biology. New York: John Wiley and Sons.

Avery, S. V. (2001). Metal toxicity in yeasts and the role of oxidative stress. Adv Appl Microbiol 49, 111-142. 
Avery, S. V., Howlett, N. G. \& Radice, S. (1996). Copper toxicity towards Saccharomyces cerevisiae: dependence on plasma membrane fatty acid composition. Appl Environ Microbiol 62, 3960-3966.

Avery, A. M., Willetts, S. A. \& Avery, S. V. (2004). Genetic dissection of the phospholipid hydroperoxidase activity of yeast Gpx3 reveals its functional importance. J Biol Chem 279, 46652-46658.

Bigelow, D. J. \& Squier, T. C. (2005). Redox modulation of cellular signaling and metabolism through reversible oxidation of methionine sensors in calcium regulatory proteins. Biochim Biophys Acta 1703, 121-134.

Bishop, A. L., Rab, F. A., Sumner, E. R. \& Avery, S. V. (2007). Phenotypic heterogeneity can enhance rare-cell survival in 'stresssensitive' yeast populations. Mol Microbiol 63, 507-520.

Boiteux, S. \& Radicella, J. P. (1999). Base excision repair of 8hydroxyguanine protects DNA from endogenous oxidative stress. Biochimie 81, 59-67.

Bradford, M. M. (1976). Rapid and sensitive method for quantitation of microgram quantities of protein utilizing the principle of proteindye binding. Anal Biochem 72, 248-254.

Cashikar, A. G., Duennwald, M. \& Lindquist, S. L. (2005). A chaperone pathway in protein disaggregation - Hsp26 alters the nature of protein aggregates to facilitate reactivation by Hsp104. J Biol Chem 280, 23869-23875.

Chen, O. S. \& Kaplan, J. (2000). CCC1 suppresses mitochondrial damage in the yeast model of Friedreich's ataxia by limiting mitochondrial iron accumulation. J Biol Chem 275, 7626-7632.

Chen, O. S., Crisp, R. J., Valachovic, M., Bard, M., Winge, D. R. \& Kaplan, J. (2004). Transcription of the yeast iron regulon does not respond directly to iron but rather to iron-sulfur cluster biosynthesis. J Biol Chem 279, 29513-29518.

Ciorba, M. A., Heinemann, S. H., Weissbach, H., Brot, N. \& Hoshi, T. (1997). Modulation of potassium channel function by methionine oxidation and reduction. Proc Natl Acad Sci U S A 94, 9932-9937.

Courel, M., Lallet, S., Camadro, J. M. \& Blaiseau, P. L. (2005). Direct activation of genes involved in intracellular iron use by the yeast ironresponsive transcription factor Aft2 without its paralog Aft1. Mol Cell Biol 25, 6760-6771.

Delaye, L., Becerra, A., Orgel, L. \& Lazcano, A. (2007). Molecular evolution of peptide methionine sulfoxide reductases (MsrA and $\mathrm{MsrB}$ ): on the early development of a mechanism that protects against oxidative damage. J Mol Evol 64, 15-32.

Ezraty, B., Grimaud, R., El Hassouni, M., Moinier, D. \& Barras, F. (2004). Methionine sulfoxide reductases protect $\mathrm{Ffh}$ from oxidative damages in Escherichia coli. EMBO J 23, 1868-1877.

Gietz, R. D. \& Woods, R. A. (2002). Transformation of yeast by the lithium acetate/single-stranded carrier DNA/polyethylene glycol method. Methods Enzymol 350, 87-96.

Hausmann, A., Samans, B., Lill, R. \& Mühlenhoff, U. (2008). Cellular and mitochondrial remodeling upon defects in iron-sulfur protein biogenesis. J Biol Chem 283, 8318-8330.

Hughes, M. N. \& Poole, R. K. (1991). Metal speciation and microbial growth - the hard (and soft) facts. J Gen Microbiol 137, 725-734.

Huh, W. K., Falvo, J. V., Gerke, L. C., Carroll, A. S., Howson, R. W., Weissman, J. S. \& O'Shea, E. K. (2003). Global analysis of protein localization in budding yeast. Nature 425, 686-691.

Imlay, J. A. (2006). Iron-sulphur clusters and the problem with oxygen. Mol Microbiol 59, 1073-1082.

Irazusta, V., Cabiscol, E., Reverter-Branchat, G., Ros, J. \& Tamarit, J. (2006). Manganese is the link between frataxin and iron-sulfur deficiency in the yeast model of Friedreich ataxia. J Biol Chem 281, 12227-12232.
Janke, C., Magiera, M. M., Rathfelder, N., Taxis, C., Reber, S., Maekawa, H., Moreno-Borchart, A., Doenges, G., Schwob, E. \& other authors (2004). A versatile toolbox for PCR-based tagging of yeast genes: new fluorescent proteins, more markers and promoter substitution cassettes. Yeast 21, 947-962.

Jarrett, J. T. (2005). The novel structure and chemistry of iron-sulfur clusters in the adenosylmethionine-dependent radical enzyme biotin synthase. Arch Biochem Biophys 433, 312-321.

Jo, W. J., Loguinov, A., Chang, M., Wintz, H., Nislow, C., Arkin, A. P., Giaever, G. \& Vulpe, C. D. (2008). Identification of genes involved in the toxic response of Saccharomyces cerevisiae against iron and copper overload by parallel analysis of deletion mutants. Toxicol Sci 101, 140-151.

Johnson, D. C., Dean, D. R., Smith, A. D. \& Johnson, M. K. (2005). Structure, function, and formation of biological iron-sulfur clusters. Annu Rev Biochem 74, 247-281.

Keyer, K. \& Imlay, J. A. (1996). Superoxide accelerates DNA damage by elevating free-iron levels. Proc Natl Acad Sci U S A 93, 1363513640.

Kim, H. Y. \& Gladyshev, V. N. (2004). Methionine sulfoxide reduction in mammals: characterization of methionine-R-sulfoxide reductases. Mol Biol Cell 15, 1055-1064.

Knight, S. A. B., Labbe, S., Kwon, L. F., Kosman, D. J. \& Thiele, D. J. (1996). A widespread transposable element masks expression of a yeast copper transport gene. Genes Dev 10, 1917-1929.

Koc, A., Gasch, A. P., Rutherford, J. C., Kim, H. Y. \& Gladyshev, V. N. (2004). Methionine sulfoxide reductase regulation of yeast lifespan reveals reactive oxygen species-dependent and -independent components of aging. Proc Natl Acad Sci U S A 101, 79998004 .

Kohlhaw, G. B. (1988). Isopropylmalate dehydratase from yeast. Methods Enzymol 166, 423-429.

Kryukov, G. V., Kumar, R. A., Koc, A., Sun, Z. H. \& Gladyshev, V. N. (2002). Selenoprotein $R$ is a zinc-containing stereo-specific methionine sulfoxide reductase. Proc Natl Acad Sci U S A 99, 4245-4250.

Kumanovics, A., Chen, O. S., Li, L. T., Adkins, E. M., Lin, H., Dingra, N. N., Outten, C. E., Keller, G., Winge, D. \& other authors (2008). Identification of FRA1 and FRA2 as genes involved in regulating the yeast iron regulon in response to decreased mitochondrial iron-sulfur cluster synthesis. J Biol Chem 283, 10276-10286.

Kumar, A., Agarwal, S., Heyman, J. A., Matson, S., Heidtman, M., Piccirillo, S., Umansky, L., Drawid, A., Jansen, R. \& other authors (2002). Subcellular localization of the yeast proteome. Genes Dev 16, 707-719.

Le, D. T., Liang, X. W., Fomenko, D. E., Raza, A. S., Chong, C. K., Carlson, B. A., Hatfield, D. L. \& Gladyshev, V. N. (2008). Analysis of methionine/selenomethionine oxidation and methionine sulfoxide reductase function using methionine-rich proteins and antibodies against their oxidized forms. Biochemistry 47, 6685-6694.

Levine, R. L., Mosoni, L., Berlett, B. S. \& Stadtman, E. R. (1996). Methionine residues as endogenous antioxidants in proteins. Proc Natl Acad Sci U S A 93, 15036-15040.

Li, L. T. \& Kaplan, J. (2004). A mitochondrial-vacuolar signaling pathway in yeast that affects iron and copper metabolism. J Biol Chem 279, 33653-33661.

Lill, R. \& Kispal, G. (2000). Maturation of cellular Fe-S proteins: an essential function of mitochondria. Trends Biochem Sci 25, 352356.

Lin, C. M. \& Kosman, D. J. (1990). Copper uptake in wild type and copper metallothionein-deficient Saccharomyces cerevisiae - kinetics and mechanism. J Biol Chem 265, 9194-9200. 
Longtine, M. S., McKenzie, A., Demarini, D. J., Shah, N. G., Wach, A., Brachat, A., Philippsen, P. \& Pringle, J. R. (1998). Additional modules for versatile and economical PCR-based gene deletion and modification in Saccharomyces cerevisiae. Yeast 14, 953-961.

Melkani, G. C., Kestetter, J., Sielaff, R., Zardeneta, G. \& Mendoza, J. A. (2006). Protection of GroEL by its methionine residues against oxidation by hydrogen peroxide. Biochem Biophys Res Commun 347, 534-539.

Molik, S., Lill, R. \& Mühlenhoff, U. (2007). Methods for studying iron metabolism in yeast mitochondria. Methods Cell Biol 80, 261-280.

Moskovitz, J. (2005). Methionine sulfoxide reductases: ubiquitous enzymes involved in antioxidant defense, protein regulation, and prevention of aging-associated diseases. Biochim Biophys Acta 1703, 213-219.

Moskovitz, J., Berlett, B. S., Poston, J. M. \& Stadtman, E. R. (1997). The yeast peptide methionine sulfoxide reductase functions as an antioxidant in vivo. Proc Natl Acad Sci U S A 94, 9585-9589.

Moskovitz, J., Flescher, E., Berlett, B. S., Azare, J., Poston, J. M. \& Stadtman, E. R. (1998). Overexpression of peptide-methionine sulfoxide reductase in Saccharomyces cerevisiae and human $\mathrm{T}$ cells provides them with high resistance to oxidative stress. Proc Natl Acad Sci U S A 95, 14071-14075.

Moskovitz, J., Bar-Noy, S., Williams, W. M., Berlett, B. S. \& Stadtman, E. R. (2001). Methionine sulfoxide reductase (MsrA) is a regulator of antioxidant defense and lifespan in mammals. Proc Natl Acad Sci U S A 98, 12920-12925.

Mühlenhoff, U., Gerl, M. J., Flauger, B., Pirner, H. M., Balser, S., Richhardt, N., Lill, R. \& Stolz, J. (2007). The iron-sulfur cluster proteins Isa1 and Isa2 are required for the function but not for the de novo synthesis of the Fe/S clusters of biotin synthase in Saccharomyces cerevisiae. Eukaryot Cell 6, 495-504.

Oien, D. \& Moskovitz, J. (2007). Protein-carbonyl accumulation in the non-replicative senescence of the methionine sulfoxide reductase A (msrA) knockout yeast strain. Amino Acids 32, 603-606.

Oien, D. B. \& Moskovitz, J. (2008). Substrates of the methionine sulfoxide reductase system and their physiological relevance. Curr Top Dev Biol 80, 93-133.

Payne, T., Hanfrey, C., Bishop, A. L., Michael, A. J., Avery, S. V. \& Archer, D. B. (2008). Transcript-specific translational regulation in the unfolded protein response of Saccharomyces cerevisiae. FEBS Lett 582, 503-509.

Pogocki, D. (2003). Alzheimer's $\beta$-amyloid peptide as a source of neurotoxic free radicals: the role of structural effects. Acta Neurobiol Exp (Wars) 63, 131-145.

Portnoy, M. E., Schmidt, P. J., Rogers, R. S. \& Culotta, V. C. (2001). Metal transporters that contribute copper to metallochaperones in Saccharomyces cerevisiae. Mol Genet Genomics 265, 873-882.

Puig, S., Lee, J., Lau, M. \& Thiele, D. J. (2002). Biochemical and genetic analyses of yeast and human high affinity copper transporters suggest a conserved mechanism for copper uptake. J Biol Chem 277, 26021-26030.

Puig, S., Askeland, E. \& Thiele, D. J. (2005). Coordinated remodeling of cellular metabolism during iron deficiency through targeted mRNA degradation. Cell 120, 99-110.

Ramirez, D. C., Mejiba, S. E. G. \& Mason, R. P. (2005). Coppercatalyzed protein oxidation and its modulation by carbon dioxide enhancement of protein radicals in cells. J Biol Chem 280, 2740227411.

Rutherford, J. C., Jaron, S. \& Winge, D. R. (2003). Aft $1 p$ and Aft $2 p$ mediate iron-responsive gene expression in yeast through related promoter elements. J Biol Chem 278, 27636-27643.
Rutherford, J. C., Ojeda, L., Balk, J., Mühlenhoff, U., Lill, R. \& Winge, D. R. (2005). Activation of the iron regulon by the yeast Aft $1 / \mathrm{Aft} 2$ transcription factors depends on mitochondrial but not cytosolic iron-sulfur protein biogenesis. J Biol Chem 280, 10135-10140.

Sanz, A., Caro, P., Ayala, V., Portero-Otin, M., Pamplona, R. \& Barja, G. (2006). Methionine restriction decreases mitochondrial oxygen radical generation and leak as well as oxidative damage to mitochondrial DNA and proteins. FASEB J 20, 1064-1073.

Schoneich, C. (2005). Methionine oxidation by reactive oxygen species: reaction mechanisms and relevance to Alzheimer's disease. Biochim Biophys Acta 1703, 111-119.

Shan, Y. X., Napoli, E. \& Cortopassi, G. (2007). Mitochondrial frataxin interacts with ISD11 of the NFS1/ISCU complex and multiple mitochondrial chaperones. Hum Mol Genet 16, 929-941.

Small, I., Peeters, N., Legeai, F. \& Lurin, C. (2004). Predotar: a tool for rapidly screening proteomes for $\mathrm{N}$-terminal targeting sequences. Proteomics 4, 1581-1590.

Smith, M. C. A., Sumner, E. R. \& Avery, S. V. (2007). Glutathione and Gtslp drive beneficial variability in the cadmium resistances of individual yeast cells. Mol Microbiol 66, 699-712.

Srinivasan, C., Liba, A., Imlay, J. A., Valentine, J. S. \& Gralla, E. B. (2000). Yeast lacking superoxide dismutase(s) show elevated levels of "free iron" as measured by whole cell electron paramagnetic resonance. J Biol Chem 275, 29187-29192.

Stoj, C. S., Augustine, A. J., Solomon, E. I. \& Kosman, D. J. (2007). Structure-function analysis of the cuprous oxidase activity in Fet3p from Saccharomyces cerevisiae. J Biol Chem 282, 7862-7868.

Strain, J., Lorenz, C. R., Bode, J., Garland, S., Smolen, G. A., Tall, D. T., Vickery, L. E. \& Culotta, V. C. (1998). Suppressors of superoxide dismutase (SOD1) deficiency in Saccharomyces cerevisiae - identification of proteins predicted to mediate iron-sulfur cluster assembly. J Biol Chem 273, 31138-31144.

Sumner, E. R., Shanmuganathan, A., Sideri, T. C., Willetts, S. A., Houghton, J. E. \& Avery, S. V. (2005). Oxidative protein damage causes chromium toxicity in yeast. Microbiology 151, 1939-1948.

Sun, H. Y., Gao, J., Ferrington, D. A., Biesiada, H., Williams, T. D. \& Squier, T. C. (1999). Repair of oxidized calmodulin by methionine sulfoxide reductase restores ability to activate the plasma membrane Ca-ATPase. Biochemistry 38, 105-112.

Temple, M. D., Perrone, G. G. \& Dawes, I. W. (2005). Complex cellular responses to reactive oxygen species. Trends Cell Biol 15, 319-326.

Wallace, M. A., Bailey, S., Fukuto, J. M., Valentine, J. S. \& Gralla, E. B. (2005). Induction of phenotypes resembling CuZn-superoxide dismutase deletion in wild-type yeast cells: an in vivo assay for the role of superoxide in the toxicity of redox-cycling compounds. Chem Res Toxicol 18, 1279-1286.

Wassef, R., Haenold, R., Hansel, A., Brot, N., Heinemann, S. H. \& Hoshi, T. (2007). Methionine sulfoxide reductase A and a dietary supplement $S$-methyl- $L$-cysteine prevent Parkinson's-like symptoms. J Neurosci 27, 12808-12816.

Waters, B. M. \& Eide, D. J. (2002). Combinatorial control of yeast FET4 gene expression by iron, zinc, and oxygen. J Biol Chem 277, 33749-33757.

Wingert, R. A., Galloway, J. L., Barut, B., Foott, H., Fraenkel, P., Axe, J. L., Weber, G. J., Dooley, K., Davidson, A. J. \& other authors (2005). Deficiency of glutaredoxin 5 reveals $\mathrm{Fe}-\mathrm{S}$ clusters are required for vertebrate haem synthesis. Nature 436, 1035-1039.

Yamaguchi-Iwai, Y., Dancis, A. \& Klausner, R. D. (1995). AFT1 - a mediator of iron regulated transcriptional control in Saccharomyces cerevisiae. EMBO J 14, 1231-1239.

Edited by: D. J. Jamieson 